\title{
Metacercariae of Austrodiplostomum compactum (Lutz, 1928) (Trematoda, Diplostomidae) infecting the eyes of Plagioscion squamosissimus (Heckel, 1840) (Perciformes, Scienidae) from Lake Catalão, Amazonas, Brazil
}

\author{
Natália Brandão de ALBUQUERQUE ${ }^{1}$ Germán Augusto Murrieta MOREY²*; Aprigio Mota MORAIS³; \\ José Celso de Oliveira MALTA ${ }^{3}$ \\ Universidade Federal do Amazonas, Av. General Rodrigo Otávio, 6200 - Coroado I, Manaus, Amazonas, Brazil 69067-005. Programa de Pós-graduação em Ciências Pesqueiras \\ nos Trópicos-PGCIPET. \\ 2 Instituto Nacional de Pesquisas da Amazônia, Av. André Araújo, 2936 - Petrópolis, Manaus, Amazonas, Brazil 69067-375. Programa de Pós-graduação em Biologia de Água \\ Doce e Pesca Interior-BADPI \\ 3 Instituto Nacional de Pesquisas da Amazônia, Coordenação de Biodiversidade, Laboratório de Parasitologia e Patologia de Peixes, Av. André Araújo, 2936 - Petrópolis, Manaus, \\ Amazonas, Brazil 69067-375 \\ * Corresponding author: germantiss@hotmail.com
}

\begin{abstract}
Austrodiplostomum compactum is a digenetic trematode whith metacercariae that occur in the eyes of a wide variety of fish species. In Brazil, $A$. compactum metacercariae have been reported in many fish species, but there are only a few studies in the Amazon region. Due to the lack of information in the Amazon, the aim of this study was to report the occurrence of A. compactum metacercariae in the eyes of 15 specimens of Plagioscion squamosissimus from the Lake Cataláo, in Amazonas, Brazil. Fishes were collected using gill nets placed randomly in the lake, euthanized in a field laboratory, and had their eyes dissected and examined under a stereomicroscope. A total of 801 metacercariae were registered infecting the eyes of the hosts with a parasitic prevalence of $100 \%$. There was a significant positive correlation between the number of metacercariae recorded and the standard body length of fishes. No significant correlation was found between the number of metacercariae and the weight and relative condition factor $(\mathrm{Kn})$ of the hosts. Values of the variance-to-mean ratio and Green's index suggested an aggregate distribution of the parasites in the hosts, with a low degree of aggregation. This is the first report of occurrence of A. compactum parasitizing a fish in the Lake Cataláo.
\end{abstract}

KEYWORDS: corvina fish, Digenea, parasites, infection

\section{Metacercárias de Austrodiplostomum compactum (Lutz, 1928) (Trematoda, Diplostomidae) infectando os olhos de Plagioscion squamosissimus (Heckel, 1840) (Perciformes, Scienidae) do Lago Catalão, Amazonas, Brasil}

\section{RESUMO}

Austrodiplostomum compactum é um trematódeo digenético cuja metacercária ocorre nos olhos de uma grande variedade de espécies de peixes. No Brasil, metacercárias deste parasita foram relatadas em diversas espécies de peixes, mas existem poucos estudos na região amazônica. Devido à falta de informação na região amazônica, o objetivo deste estudo foi relatar a ocorrência de metacercárias de $A$. compactum nos olhos de 15 espécimes de Plagioscion squamosissimus provenientes do Lago Cataláo, Amazonas, Brasil. Os peixes foram coletados usando redes de pesca distribuídas aleatoriamente no lago e sacrificados em laboratório de campo, onde os olhos foram removidos e examinados sob microscópio estereoscópico. Um total de 801 metacercárias foram registradas infectando os olhos do hospedeiro, com uma prevalência parasitária de $100 \%$. Houve uma correlação positiva significativa entre o número de metacercárias e o comprimento padráo dos peixes. Nenhuma correlaçáo significativa entre o número de metacercárias e o peso e o fator de condiçáo relativa (Kn) dos hospedeiros foi evidenciada. Valores do índice de dispersáo e do índice de Green sugerem uma distribuição agregada dos parasitas com um baixo grau de agregação nos hospedeiros. Este é o primeiro relato da ocorrência de $A$. compactum parasitando um peixe no Lago Cataláo.

PALAVRAS-CHAVE: corvina, Digenea, parasitas, infecção, peixes 


\section{INTRODUCTION}

Parasites with heteroxenous life cycles depend on trophic transmission. Infected hosts have to be ingested by the next host in the life cycle for successful transmission (Holmes and Bethel, 1972). Diplostomid species require three hosts to complete their cycle, including a piscivorous bird as a definitive host, a snail first-intermediate host and a fish secondintermediate host (Karvonen et al. 2004).

Adult parasites are found in the intestine of piscivorous birds. Their eggs are shed with the avian host's feces and a free-swimming miracidium hatches from each egg to seek and penetrate a snail. Inside the snail, the miracidum develops into a mother sporocyst, which reproduces asexually to produce daughter sporocysts. Each of these daughter sporocysts reproduces asexually to produce cercariae (infective stages). Thousands of cercariae may be released from a single snail in search of a fish which they penetrate through the gills to subsequently develop into metacercariae in the fish's eyes. The avian final host acquires the metacercariae by consuming an infected fish (Chappell et al. 1994).

Diplostomid metacercariae can alter fish behaviour (Seppala et al. 2004) and cause diseases in their hosts, causing severe ocular pathology associated with cataracts and blindness and, in some cases, lead to death (Valtonen and Gibson, 1997). The formation of cataract in fishes infected by diplostomid metacercariae is more intense after the parasites complete their development and are ready to infect the final host, increasing the susceptibility of the fish host to predation. This is a highly efficient transmission method of these parasites (Mouritsen and Poulin 2003).

Hosts, defined as shelter, mating point and food resource for parasites, consist of replicated habitats in time and space. Host-parasite systems are undoubtedly interesting models for understanding patterns and processes in community ecology (Price 1990). Host size and age have an effect on parasite communities, since larger hosts are also older and have been exposed to parasite colonization for a longer period. Moreover, as fish body size increases, the body area increases, thus permitting a larger number of parasites to infect hosts (Bell and Burt, 1991).

The aggregated distribution pattern tends to increase stability in the host-parasite relationship, and may increase the reproductive efficiency of some adult parasites. In this kind of distribution severe effects caused by high infection intensity may be restricted to few individuals instead of affecting the whole population (Dobson 1990).

The relative condition factor of fishes is an indicator of parasitism levels and it has been used in recent decades as an important tool for the study of host-parasite interactions (Lizama et al. 2006). The analysis of the variation of this indicator among populations and individuals can be used to show the effect of parasite species on their hosts in natural environments (Ranzani-Paiva et al. 2000).

Species of the Diplostomidae family have been found in fishes in Asia, Europe, North America and South America (Niewiadomska, 1996). In Brazil the diplostomid Austrodiplostomum compactum has been reported in approximately 25 fish species (Machado et al. 2005; Eiras et al. 2010; Paes et al. 2010).

One of the described hosts of $A$. compactum is Plagioscion squamosissimus (Heckel, 1840), a fish species native to the Amazonas River basin, including the Tocantins-Araguaia subbasin, in northern Brazil (Agostinho et al., 2007). Studies on the diet of the species characterize it as carnivore consuming, basically, crustaceans and fish (Goulding and Ferreira, 1984). A. compactum has been studied more frequently as a endoparasite of $P$. squamosissimus in rivers where this fish is introduced (Kohn et al., 1995; Silva-Souza, 1998; Martins et al., 1999; Machado et al., 2005).

This work reports the first infection case of $A$. compactum metacercariae in P. squamosissimus from Lake Catalão (central Amazonia), where it is part of the native fish fauna. It is also the first record of $A$. compactum in any fish in Lake Cataláo. We describe the distribution pattern of $A$. compactum in the $P$. squamosissimus population, and analyze the relation of host size, weight and relative condition factor with the infection level.

\section{MATERIALS AND METHODS}

Fifteen specimens of Plagioscion squamosissimus were collected on December 2015 using gill nets placed at random points in Lake Catalão ( $3^{\circ} 09^{\prime} 47^{\prime \prime} \mathrm{S}$ and $059^{\circ} 54^{\prime} 29^{\prime \prime} \mathrm{W}$ ), a floodplain lake located at the confluence of the Negro and Solimóes rivers (Amazonas, Brazil). The hydrological balance of Lake Cataláo is greatly influenced by the relative magnitudes of the influx of the Solimóes and Negro rivers, and can be described as a variable mixture of these two chemically distinct sources, therefore, there is a very particular temporal and spatial sequence of physical and chemical characteristics for this lake (Almeida \& Melo, 2009).

For parasitological analysis, the fishes were quickly immersed in a $75 \mathrm{mg}$ clove oil. $\mathrm{L}^{-1}$ solution and euthanized (CONCEA 2013). Posteriorly, fishes were measured and weighed, and had both eyes removed. The parasites were removed from the eyes, counted and processed according to Eiras et al. (2006). Metacercariae were removed from the vitreous humor and fixed in AFA (alcohol - formaldehyde and acetic acid) solution under cover slip pressure. Specimens were stained with Langeron's alcoholic carmine, cleared in Eugenol and mounted in Canada balsam as permanent slides. 
Taxonomical identification was according to Travassos et al. (1969) and Kohn et al. (1995).

Morphometric analyses were performed using a computerized system for analysis of images, QWin Lite 2.5 (Leica). Voucher specimens were deposited in the zoological collection of the Instituto Nacional de Pesquisas da Amazônia (INPA). The ecological terms in parasitology follow Bush et al. (1997): prevalence $(\mathrm{P})$ is the number of infected fish with one or more individuals of a particular parasite species (or taxonomic group) divided by the number of hosts examined (expressed as a percentage). Intensity of infection (I) is the number of individuals of a particular parasite species in a single infected host (expressed as a numerical range); mean intensity of infection $(\mathrm{mI})$ is the average intensity, or the total number of parasites of a particular species found in a sample divided by the number of infected hosts; and mean abundance of infection $(\mathrm{mA})$ is the average abundance, or the total number of parasites of a particular species found in a sample divided by the total number of hosts.

The condition factor is a quantitative indicator of fish health, reflecting recent feeding conditions and is obtained using the weight-length relation of the individual. Values of standard length (L) and total weight (Wt) of each host were adjusted to the relationship curve Wt/ Ls $\left(\mathrm{Wt}=\mathrm{a} \cdot \mathrm{Lt}^{\mathrm{b}}\right)$ and were used to estimate values of the regression coefficients " $\mathrm{a}$ " and " $\mathrm{b}$ ". The $a$ and $b$ values were used for estimating expected values for weight (We) using the equation: $\mathrm{We}=\mathrm{a} \cdot \mathrm{Lt}^{\mathrm{b}}$. The relative condition factor $(\mathrm{Kn})$ corresponds to the ratio between observed weight and expected weight for a given length $(\mathrm{Kn}=$ Wt/ We) (Le Cren 1951).

The Shapiro-Wilk $W$ statistic was used to test for normality of distributions. Pearson's correlation test with previous transformation of the number of metacercariae recorded in each fish $\left(\log _{10}\right)$ was used to evaluate the correlation between the total number of metacercariae and the fish standard length, weight and relative condition factor.

The variance-to-mean-ratio (VMR) and the Green index (GI) were used to examine dispersion patterns of the metacercariae (Ludwig and Reynolds 1988). Green's index was used to compare samples that vary in the total number of individuals, their sample means and the number of sample units in the sample. GI varies between 0 (for random) and

1 (for maximum clumping) (Ludwig and Reynolds 1988). Statistical significance was set at $P<0.05$. Data were analyzed using the software BioEstat 5.0

\section{RESULTS}

Fifteen specimens of Plagioscion squamosissimus with 20.4 $\pm 2.9 \mathrm{~cm}$ standard length and $158.7 \pm 51.5 \mathrm{~g}$ weight were infected in the humor vitreous with A. compactum (Figure 1),

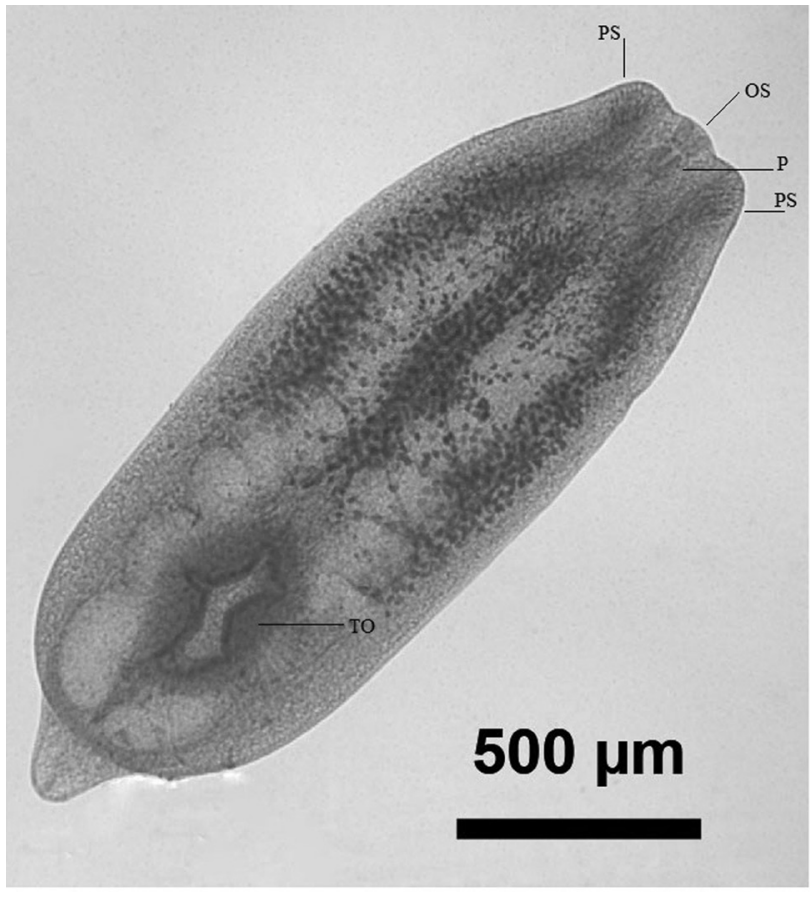

Figure 1. Austrodiplostomum compactum (Diplostomidae) metacercaria found in an eye of Plagioscion squamosissimus (Scianidae) from Lago Catalão (Brazilian Amazon). Ventral view, with oral suckers (OS), pseudosuckers (PS), pharynx (P), and tribocytic organ (TO).

with prevalence $=100 \%$. A total of 801 metacercariae were recovered, ranging from 2 to 210 specimens per fish. The values of $\mathrm{mI}$ and $\mathrm{mA}$ were the same $(53.4 \pm 65.2$ parasites $)$ since prevalence was $100 \%$.

Austrodiplostomum compactum metacercariae had a foliaceous body, slightly concave on the ventral face, small conical segments in the posterior region, a small subterminal oral sucker, two lateral pseudosuckers in the anterior region, an oval pharynx, short esophagus, intestinal caeca ending near the posterior region, an oval tribocytic organ, gland cells occupying most of the anterior region, extending from the beginning of intestinal caeca in the anterior region to the tribocytic organ. Data on the morphometry of $A$. compactum metacercariae are summarized in Table 1.

There was a significant positive correlation between the intensity of infection (I) and the standard length of fishes $(r$ $=0.5681, p=0.0271$ ) (Figure 2). No significant correlation was found between I and the weight $(r=0.466 ; p=0.079)$ and relative condition factor $(\mathrm{Kn})$ of the hosts $(r=-0.099 ; p=$ $0.723)$. Values of the variance-to-mean-ratio $(\mathrm{VMR}=79.73)$ and Green's index $(\mathrm{GI}=0.098)$ for $A$. compactum parasitizing $P$. squamosissimus suggested an aggregate distribution of the parasites in the host with a low degree of aggregation. 


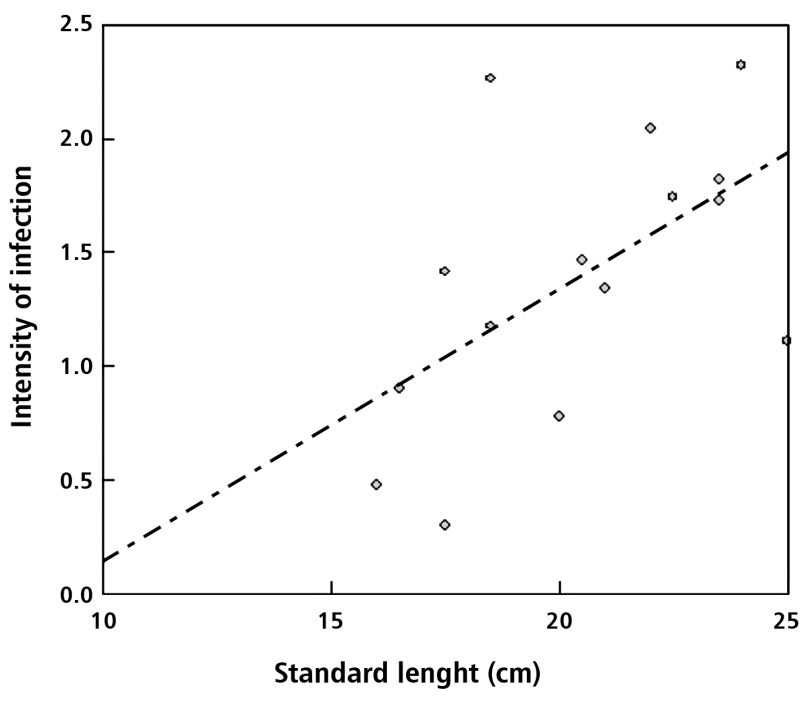

Figure 2. Correlation between the standard length and intensity of infection of metacercariae of Austrodiplostomum compactum in the eyes of Plagioscion squamosissimus from Lake Catalão, Amazonas, Brazil ( $r=0.56 ; p=0.02)$.

Table 1. Morphometrical data of 15 Austrodiplostomum compactum metacercariae infecting the eyes of Plagioscion squamosissimus. Measurements are in $\mu \mathrm{m}$ (mean \pm standard deviation, followed by minimum and maximum values).

\begin{tabular}{lc}
\hline Morphological trait & Measurement \\
\hline Lenght & $1783.5 \pm 118.3(148.2-2024.4)$ \\
\hline Width & $662.2 \pm 56.2(589.1-782.4)$ \\
\hline Lenght of anterior segment & $1654.6 \pm 103.6(1368.3-1863.7)$ \\
\hline Width of anterior segment & $662.2 \pm 56.2(138.5-288.9)$ \\
\hline Lenght of posterior segment & $128.6 \pm 35.3(57.2-184.2)$ \\
\hline Width of posterior segment & $194.6 \pm 39.6(138.4-288.7)$ \\
\hline Lenght of oral sucker & $60.5 \pm 8.7(44.8-72.4)$ \\
\hline Width of oral sucker & $70.1 \pm 8.9(47.6-81.7)$ \\
\hline Pharynx lenght & $62.9 \pm 8.4(46.9-79.4)$ \\
\hline Pharynx width & $57 \pm 8.4(41.3-69)$ \\
\hline Right pseudosucker lenght & $103.8 \pm 10.7(74.1-127.4)$ \\
\hline Right pseudosucker width & $80.6 \pm 13.1(59.5-95.1)$ \\
\hline Left pseudosucker lenght & $99.5 \pm 13.7(83.6-121.7)$ \\
\hline Left pseudosucker width & $83.1 \pm 8.4(63.7-105.6)$ \\
\hline Tribocytic organ lenght & $344.9 \pm 54.4(230.3-425.2)$ \\
\hline Tribocytic organ width & $181.1 \pm 32.2(122.2-238.2)$ \\
\hline Anterior genital primordial lenght & $47.7 \pm 6.5(34.8-59.6)$ \\
\hline Anterior genital primordial width & $46.9 \pm 7.4(35.6-62.6)$ \\
\hline Posterior genital primordial lenght & $52.1 \pm 8.7(36.7-67.9)$ \\
\hline Posterior genital primordial width & $46.5 \pm 8.5(38.1-64.9)$ \\
\hline
\end{tabular}

\section{DISCUSSION}

The prevalence of diplostomid species in introduced fish is higher when compared with that of native fish (Chabros and Pojmanska, 1993). In the upper Paraná River floodplain in Brazil A. compactum infection levels were higher in introduced fish species as compared with native species (Machado et al. 2005).

Austrodiplostomum sp. larvae were reported in the aqueous humour of P. squamosissimus from three different localities: Paraná, Solimóes, and Tocantins rivers. The higher infection rates were reported in the river Paraná where P. squamosissimus is an introduced fish (Lacerda et al., 2012).

A high parasitic index of $A$. compactum infecting $P$. squamosissimus, with prevalence higher than $90 \%$, was found in several areas in Brazil (Kohn et al. 1995, in the Paraná river; Martins et al. 1999; 2002, in Minas Gerais; Machado et al. 2005, in the floodplain of the upper Paraná River; Paes et al. 2010, in São Paulo state). As P. squamosissimus was introduced in these places, these authors suggest that high parasitic levels of infection are due to the introduction of the parasite along with the host.

The high abundance of Austrodiplostomum sp. in $P$. squamosissimus in the Paraná River basin (Kohn et al., 1995; Silva-Souza, 1998; Machado et al., 2005) and the records of this eye fluke parasitizing native hosts (Yamada et al., 2008; Zica et al., 2009) had led some authors to suggest that the diplostomid is an invasive species in the upper Paraná River (Machado et al., 2005). According to Lacerda et al.(2012) this is unlikely, so, instead of introducing a new parasite into the new habitat, it seems more probable that $P$. squamosissimus may be acting as a new host for a local parasite, acting as a reservoir for native parasites from which infections flow back to native hosts.

Austrodiplostomum compactum has low host-specificity, as it is present in many fish families with different behaviour and biology, but seems to have a preference for P. squamosissimus, considering the consistently high metacercariae infection levels reported in this species. High infection levels also suggest that $P$. squamosissimus is highly susceptible to infection by A. compactum, and may even reflect the presence of a large abundance of intermediate and definitive hosts. In the present study all sampled hosts were infected with $A$. compactum (100\% prevalence) which supports these hypotheses.

With the increase of the standard length of the host, the area of the body surface also increases, as well as the possibility of active penetration of cercariae (Luque et al. 1996). In 50 fish species from the coast of Brazil a positive correlation was found between host body length and helminth larvae abundance (Luque et al. 2004). Machado et al. (2005) and Paes et al. (2010) found a positive correlation between the intensity of infection of $A$. compactum and the standard length 
of $P$. squamosissimus, as was the case in this study, supporting the notion that metacercariae intensity of infection increases with the amount of body surface available for infection.

In populations of P. squamosissimus from the upper Paraná River, metacercariae of $A$. compactum presented aggregated distribution with a low degree of aggregation (Machado et al. 2005). In this type of distribution, many individuals of the host population are not parasitized, while few hosts shelter many parasites (Ludwig and Reynolds, 1988). The same distribution pattern of parasites was recorded in this study. All sampled P. squamosissimus were infected by $A$. compactum, but some sheltered many metacercariae and others only a few. Thus, the possibility of severe effects caused by elevated intensities of infection may be restricted to a small part of the host population.

High infection levels of metacercariae in the eyes of fish can reduce their alimentary efficiency, leading to weight loss (Chappel 1994). Silva and Souza (1988) found that $P$. squamosissimus infected by metacercariae of $A$. compactum had lower values of relative condition factor than non infected fish, while Machado et al. (2005) found no difference in the health condition of fishes related to the infection by $A$. compactum. Likewise, we found no indication of an effect of the intensity of infection by metacercariae in the eyes of fishes and their relative condition factor. As all the sampled fish were infected by $A$. compactum metacercariae it was not possible to compare health condition between infected and non infected fishes.

In the Amazon there are two main hydrological periods: the high water season (from January until July in the central Amazon), when large areas are flooded, and the low water season (from July to December), characterized by a drastic reduction of the water availability, leading to the concentration and spatial overlap of different organisms (Lowe-McConell 1999). In smaller water volumes parasite transmission may be intensified as a result of increased spatial overlap of hosts involved in the parasite`s life cycle (Marcogliese et al. 2001), which may explain the high parasite prevalence in our sample, that was obtained in December, during low water levels. Lentic habitats, like Lake Cataláo, are characterized by extensive macrophyte growth, providing suitable habitat for the intermediate gastropod hosts of $A$. compactum. In addition, slower currents likely permit greater retention of both snails and free-swimming cercariae (Marcogliese et al. 2001).

\section{CONCLUSIONS}

The high parasitism rates by $A$. compactum metacercariae in P. squamosissimus indicates that this fish species occupies an intermediate position in the food chain and is a likely part of the diet of piscivorous birds, the definitive hosts of this parasite species. Our data support the notion that $P$. squamosissimus is highly susceptible to infection by this diplostomid in the given presence of the first intermediate and final hosts.

\section{ACKNOWLEDGEMENTS}

We are indebted to the Fish Parasitology Laboratory team at INPA for the technical assistance they provided throughout this study. Natália Brandão de ALBUQUERQUE and Germán Augusto Murrieta MOREY were supported by scholarships from the Coordenação de Aperfeiçoamento de Pessoal de Nível Superior - CAPES (Brazil).

\section{REFERENCES}

Agostinho, A. A.; Gomes, L. C.; Pelicice, F. M. 2007. Ecologia e manejo de recursos pesqueiros em reservatórios do Brasil. EDUEM, Maringá, 260p.

Almeida, F.F., Melo, S. 2009. Consideraçôes limnológicas sobre um lago da planície de inundaçáo amazônica (lago Catalao - Amazonas - Brasil). Acta Scientiarum: Biological Sciences, 31: 387-395.

Bell, G.; Burt, A. 1991. The comparative biology of parasite species diversity: intestinal helminths of freshwater fishes. Journal of Animal Ecology, 60: 1046-1063.

Bush, A. O., Lafferty, K.D., Lotz, J.M., Shostak, A.W. 1997. Parasitology meets ecology on its own terms: Margolis et al. revisited. The Journal of Parasitology, 83: 575-583.

Chabros, M.; Pojmanska, T. 1993. Parasites of common carp and three introduced cyprinid fish in pond culture. Acta parasitologica, 38: 101-108.

Chappell, L.H.; Hardie, L.J.; Secombes, C.J. 1994. Diplostomiasis: the disease and host-parasite interactions. In: Pike, A.W \& Lewis, J.W (Ed.). Parasitic Diseases of Fish, Dyfed, UK, p. 59-86.

CONCEA, 2013. Diretrizes da Prática de Eutanásia do Conselho Nacional de Controle de Experimentação Animal - CONCEA. Ministério da Ciência, Tecnologia e Inovação, Brasília, DF. 54 p.

Dobson, A.P. 1990. Models for multi-species parasite-host communities. In: Esch, G.W; Bush, J.M; Aho, J.M. (Ed.). Parasite communities: Patterns and processes. Springer, Netherlands, p. 261-288.

Eiras, C.J.; Takemoto, M.R.; Pavanelli, G.C. 2006. Métodos de estudo e técnicas laboratoriais em parasitologia de peixes. $2 \mathrm{da}$ ed. EDUEM, Maringá. 199p.

Eiras, J.C.; Takemoto, R.M.; Pavanelli, G.C.; Adriano, E.A. 2010. Diversidade dos parasitas de peixes de água doce do Brasil. Clichetec, Maringá. 2389p.

Goulding, M., Ferreira, E. 1984. Shrimp-eating fishes and a case of prey switching in Amazon rivers. Revista Brasileira de Zoologia 2: 85-97.

Holmes, J.C.; Bethel, W.M. 1972. Modification of intermediate host behaviour by parasites. In: Canning, E.U; Wright, C.A. (Ed.). Behavioural aspects of parasite transmission. Linnean Society of London, London, v.51. p. 123-149.

Karvonen, A.; Seppälä, O.; Valtonen, E.T. 2004. Eye fluke-induced cataract formation in fish: quantitative analysis using an ophthalmological microscope. Parasitology, 129: 473-478. 
Kohn, A.; Fernandes, B.M.; Baptista-Farias, M.D.F.D. 1995. Metacercariae of Diplostomum (Austrodiplostomum) compactum (Trematoda, Diplostomidae) in the eyes of Plagioscion squamosissimus (Teleostei, Sciaenidae) from the reservoir of the Hydroeletric Power Station of Itaipu, Brazil. Memórias do Instituto Oswaldo Cruz, 90: 341-344.

Lacerda, A.C.F.; Takemoto, R.M.; Tavares-Dias, M.; Poulin, R.; Pavanelli, G.C. 2012. Comparative parasitism of the fish Plagioscion squamosissimus in native and invaded river basins. Journal of Parasitology, 98: 713-717.

Le Cren, E.D. 1951. The length-weight relationship and seasonal cycle in gonad weight and condition in the perch Perca fluviatilis. Journal of Animal Ecology, 20: 201-219.

Lizama, M.A.P.; Takemoto, R.M.; Pavanelli, G.C. 2006. Parasitism influence on the hepato, splenosomatic and weight/length relation and relative condition factor of Prochilodus lineatus (Valenciennes, 1836) (Prochilodontidae) of the Upper Paraná River floodplain, Brazil. Revista Brasileira de Parasitologia Veterinária, 15: 116-122.

Lowe-McConnell, R.H. 1999. Estudos ecológicos de comunidades de peixes tropicais. Coleção Base, EDUSP, São Paulo. 534p.

Ludwig, J.A.; Reynolds, J.F. 1988. Statistical ecology: a primer in methods and computing. 2nd ed. John Wiley \& Sons, New York, 339p.

Luque, J.L.; Amato, J.F.R.; Takemoto, R.M. 1996. Comparative analysis of the communities of metazoan parasites of Orthopristis ruber and Haemulon steindachneri (Osteichthyes: Haemulidae) from the southeastern Brazilian littoral: I. structure and influence of the size and sex of hosts. Revista Brasileira de Biologia, 56: 279-292.

Luque, J.L.; Mouillot, D.; Poulin, R. 2004. Parasite biodiversity and its determinants in coastal marine teleost fishes of Brazil. Parasitology, 128: 671-682.

Machado, P.M.; Takemoto, R.M.; Pavanelli, G.C. 2005. Diplostomum (Austrodiplostomum) compactum (Lutz, 1928) (Platyhelminthes, Digenea) metacercariae in fish from the floodplain of the Upper Paraná River, Brazil. Parasitology Research, 97: 436-444.

Marcogliese, D.J.; Dumont, P.; Gendron, A.D.; Mailhot, Y.; Bergeron, E.; McLaughlin, J.D. 2001. Spatial and temporal variation in abundance of Diplostomum spp. in walleye (Stizostedion vitreum) and white suckers (Catostomus commersoni) from the St. Lawrence River. Canadian Journal of Zoology, 79: 355-369.

Martins M.L; Fujimoto R.Y.; Nascimento A.; Moraes, F.R. 1999. Ocorrência de Diplostomum sp Nordmann, 1832 (Digenea: Diplostomatidae) em Plagioscion squamosissimus Heckel, 1840, proveniente do Reservatório de Volta Grande, MG, Brazil. Acta Scientiarum, 21:263-266

Martins, M.L.; Paiva, A.D.M.; Conceição, F.; Fujimoto, R.Y.; Canello-Schalch, S.H.; Colombano, N.C. 2002. Prevalência, sazonalidade e intensidade de infecção por Diplostomum (Austrodiplostomum) compactum Lutz, 1928 (Digenea, Diplostomidae), em peixes do reservatório de Volta Grande, Estado de Minas Gerais, Brasil. Acta Scientiarum: Biological and Health Sciences, 24: 469-474.
McFarland, L.H.; Mouritsen, K.N.; Poulin, R. 2003. From first to second and back to first intermediate host: the unusual transmission route of Curtuteria australis (Digenea: Echinostomatidae). Journal of Parasitology, 89: 625-628.

Mouritsen, K.N.;Poulin, R. 2003. Parasite-induced trophic facilitation exploited by a non-host predator: a manipulator's nightmare. International Journal for Parasitology, 33: 1043-1050.

Niewiadomska, K. 1996. The genus Diplostomum - taxonomy, morphology and biology. Acta Parasitologica, 41: 55-66

Paes, J.V.K.; Carvalho, E.D.; Silva, R.J. 2010. Infection by Austrodiplostomum compactum metacercariae in fish from the Nova Avanhandava reservoir, Tietê river, São Paulo State. Acta Scientiarum. Biological Sciences, 32: 273-278.

Price, P.W. 1990. Host populations as resources defining parasite community organization. In: Esch, G.W.; Bush, A.O.; Aho, J. (Ed.). Parasite communities: patterns and processes. Springer, Netherlands, p.21-44.

Ranzani-Paiva, M.J.T.; Silva-Souza, A.T.; Pavanelli, G.C.; Takemoto, R.M. 2000. Hematological characteristics and relative condition factor $(\mathrm{Kn})$ associated with parasitism in Schizodon borellii (Osteichthyes, Anostomidae) and Prochilodus lineatus (Osteichthyes, Prochilodontidae) from Paraná river, Porto Rico region, Paraná, Brazil. Acta Scientiarum, 22: 515-521.

Seppälä, O.; Karvonen, A.;Valtonen, E.T. 2004. Parasite-induced change in host behaviour and susceptibility to predation in an eye fluke-fish interaction. Animal Behaviour, 68: 257-263.

Silva-Souza, A.T. 1998. Estudo do parasitismo de Plagioscion squamosissimus (Heckel 1940) (Perciformes, Sciaenidae) por Diplostomum (Austrodiplostomum) compactum (Lutz, 1928) (Trematoda, Digenea) no rio Tibagi, PR. Doctoral thesis, Universidade Federal de São Carlos, São Carlos, São Paulo. 192p.

Travassos, L.; Freitas, J.T.D.; Kohn, A. 1969. Trematódeos do Brazil. Memórias do Instituto Oswaldo Cruz, 67: 1-886.

Valtonen, E.T.; Gibson, D.I. 1997. Aspects of the biology of diplostomid metacercarial (Digenea) populations occurring in fishes in different localities of northern Finland. Annales Zoologici Fennici, 34: 47-59.

Yamada, F.H.; Moreira, L.H.A.; Ceschini, T.L.; Takemoto, R.M.; Pavanelli, G.C. 2008. Novas ocorrências de metacercária de Austrodiplostomum compactum (Lutz, 1928) (Platyhelminthes: Digenea) parasito de olhos de peixes da bacia do Rio Paraná. Brazilian Journal of Veterinary Parasitology, 17: 163-166.

Zica, E.O.P.; Santos, K.R.; Ramos, I.P.; Zanatta, A.S.; Carvalho, E.D.; Silva, R.J. 2009. First case of an infection of the metacercariae of Austrodiplostomum compactum (Lutz, 1928) (Digenea, Diplostomidae) in Hypostomus regani (Ihering, 1905) (Siluriformes: Loricariidae). Pan-American Journal of Aquatic Sciences, 4: 35-38.

Received: 25/08/2016

Accepted: 15/02/2017 